\title{
Pain assessment of non-verbal patients undergoing bone marrow aspirations and lumbar puncture: Preliminary results
}

\author{
Consuelo Mancías-Guerra ${ }^{1}$, Sandra A. Sánchez-García1 , Ileana Velasco-Ruiz ${ }^{1}$, Rodrigo Huerta-Rangel ${ }^{1}$, \\ Sofía A. Carreño-Salcedo², and Oscar González-Llano² \\ ${ }^{1}$ Hematology Service; ${ }^{2}$ Departament of Pediatrics, “Dr. José Eleuterio González", University Hospital Universidad Autónoma de Nuevo León, Mexico
}

\begin{abstract}
Introduction: Pain assessment in non-verbal patients during medical interventions can be challenging due to communication problems. Therefore, it is necessary to use new pain measurement tools for these patients. Objective: The objective of the study was to assess the incidence of pain in patients with cerebral palsy (CP) and autism spectrum disorder (ASD) who undergo bone marrow aspiration (BMA) and lumbar puncture (LP) for cell therapy. Methods: The "Non-Communicating Children's Pain Checklist-Revised"checklist was used to observe the behavior of 15 patients diagnosed with CP and ASD before and after cell therapy. The evaluation was carried out simultaneously by a caregiver and by the staff of the medical team on three occasions. Scores $\geq 7$ were considered as the presence of moderate or severe pain. Results: Regarding the scores obtained in the second survey (30 min after the BMA and LP), the caregivers reported values of $<7$ points in 10 patients $(66.7 \%)$. At the same time, in the evaluation performed by caregivers $24 \mathrm{~h}$ after the procedure, scores of $<7$ points were reported in eight (53.3\%). The items with the highest scores in the surveys were verbal and facial expressions, social attitudes, and activities. Conclusions: The procedures carried out in cell therapy were safe and well-tolerated by this group of patients, with an incidence of pain in only $33.3 \%$, which can be considered a therapeutic alternative to improve their current condition without compromising their integrity or quality of life.
\end{abstract}

Key words: Cerebral palsy. Autism spectrum disorder. Cell therapy. Pain. Bone marrow aspiration. Lumbar puncture.

\section{Introduction}

Bone marrow aspiration (BMA) and lumbar puncture (LP) are very common procedures in patients with hematological diseases, in both hospitalized and outpatients, since they are affordable, simple, and with few technical complications for trained personnel ${ }^{1-3}$. No data were found regarding objective evaluations of pain in non-verbal patients who underwent these procedures. Even though these procedures are implemented for different reasons and with different objectives, non-verbal-patients have the same risk of experiencing pain. In this context, the use of regenerative medicine with stem cell therapy for different pathologies ${ }^{4-7}$, among these, infantile cerebral palsy (ICP) $)^{8,9}$ and autism spectrum disorder (ASD) $)^{10,11}$ is presented as an innovative therapy with promising results ${ }^{12-14}$. One of the sources for obtaining stem cells may be the bone marrow (BM), and the route of administration may be intrathecal. Hence, patients with ICP and ASD may require these types of procedures ${ }^{15}$.

On the other hand, whenever it is necessary to perform medical interventions in non-verbal patients, such as children with cerebral palsy or ASD, pain

\section{Correspondence:}

*Consuelo Mancías-Guerra

E-mail: consuelomanciasg@gmail.com
Available online: 28-06-2021

Date of reception: 01-02-2021

Date of acceptance: 13-04-2021 DOI: 10.24875/RMU.21000008
Medicina Universitaria. 2021;23(2):46-50 www.medicinauniversitaria.org

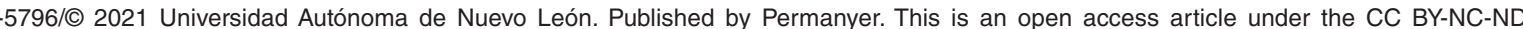
license (http://creativecommons.org/licenses/by-nc-nd/4.0/). 
assessment can be challenging because of the communication problems that this may present ${ }^{16,17}$. As a result of this difficulty, the need to use new tools for pain measurement in non-verbal patients and/or those with motor difficulties arises. There are about 14 validated scales for evaluating pain in preverbal or non-verbal patients; out of these, four can be used in patients with some degree of intellectual impairment or neurological deficit ${ }^{18}$. Of the latter, the Non-Communicating Children's Pain Checklist-Revised (NCCPC-r) stands out, designed to register the presence and intensity of pain response in children with cognitive difficulties or communication problems ${ }^{19}$.

This article aims to create a preliminary evaluation of pain incidence in patients with ICP and ASD who undergo BMA and LP when subjected to cellular therapy.

\section{Materials and Methods}

\section{Population}

In this preliminary study, thus far, a total of 15 patients were included, aged between 1 and 17 years, with a diagnosis of ICP and ASD that belong to a prospective study, which is still recruiting patients. The patients were selected regardless of their age at the time of diagnosis, time elapsed after diagnosis, type of paralysis, or severity within the autistic spectrum. The study excluded patients with genetic, autoimmune, and active infectious diseases, patients with hydrocephaly, and carriers of peritoneal-ventricular drain systems or severe meningeal anomalies.

\section{Intervention}

This study was performed at the Hematology Service at the "Dr. Jose Eleuterio Gonzalez" University Hospital of the Autonomous University of Nuevo Leon (UANL by its Spanish acronym). It is registered with the study number HE20-00017 by the Ethics in Research Committee of the Sub-directorate of Research of the School of Medicine at the same University, as well as the Ethics in Research Committee of the University Hospital. Furthermore, the Hematology Service is accredited by the Foundation for Accreditation of Cellular Therapy (FACT). This international organization regulates adult and pediatric allogeneic and autologous hematopoietic progenitor cellular therapy and cellular therapy product processing with minimal manipulation, among others. It is also accredited by the Mexican Entity of Accreditation and with a license granted by the blood bank with hematopoietic progenitor cell management no. 2039000069.

The parents signed an informed consent form after the risks involved in the procedure and explain to them in detail. A clinical background check was performed as well as a physical examination, taking laboratory samples including full hematic biometry, biochemical profile, and infection profile (hepatitis B, hepatitis C, syphilis, Brucella, HIV, and Chagas disease). Subsequently, BM stimulation began, which consisted of subcutaneous administration of granulocyte-colony stimulation factor at a dose of $10 \mu \mathrm{g} / \mathrm{kg} /$ day for 3 days. On day 4, the BMA was conducted in both posterosuperior iliac spines, under sedation with sevoflurane and local anesthesia with $2 \%$ xylocaine. A volume of $8 \mathrm{ml} /$ $\mathrm{kg}$ body weight of BM was aspirated and never exceeded $200 \mathrm{ml}$. In the end, the patient was sent to recovery while the obtained BM was taken to the lab for processing, where the buffy coat was isolated through centrifugation. The isolated buffy coat was then placed in a sterile bag and transported to the operating room, where it was applied intrathecally through an LP. This was performed in the lateral position, under sedation with propofol at $2 \mathrm{mg} / \mathrm{kg}$ in a single dose and local anesthesia with $2 \%$ xylocaine, between the lumbar vertebrae L4/L5.

Subsequently, the patients were sent to the recovery room, where they were offered clear liquids to assess oral tolerance and were discharged after $45 \mathrm{~min}$.

\section{Evaluation of pain}

The NCCPC-r ${ }^{19}$ was applied on three different occasions, the first one before performing the BMA and LP, the second one $30 \mathrm{~min}$ after both procedures, and the third evaluation $24 \mathrm{~h}$ after the procedures. Said applications were performed simultaneously by a caregiver (parents or tutors) of the patient and a medical professional evaluator, separately, on each of the previously mentioned occasions. A score of $\geq 7$ was considered to indicate the presence of moderate to severe pains ${ }^{19,20}$. This verification list comprises 30 items divided into seven groups, identified as Roman numerals (I. Vernal expression, II. Social attitude, III Facial expression, IV. Activity, V. Body and limbs, VI. Physiology, and VII. Nutrition and sleep). Each group was subdivided into items with characteristics, postures, or sounds representing pain. Each item is scored from 0 to 3 depending on the intensity and frequency and includes an exclusion value if it does not apply to the patient. 
Table 1. Demographic information

\begin{tabular}{|l|l|}
\hline Patient characteristics & $\mathbf{( n = 1 5 )}$ \\
\hline Average age (min-max) & $5(1-17)$ \\
\hline Gender & $\begin{array}{l}\text { Male } 11(73.3 \%) \\
\text { Female } 4(26.7 \%)\end{array}$ \\
\hline Diagnosis & $\begin{array}{l}\text { ICP: } 6(40 \%) \\
\text { ASD: } 9(60 \%)\end{array}$ \\
\hline Country of origin & $\begin{array}{l}\text { Mexico: } 10(66.7 \%) \\
\text { United States: } 4(26.7 \%) \\
\text { Costa Rica: } 1(6.6 \%)\end{array}$ \\
\hline Procedure number & $\begin{array}{l}\text { First: } 9(60 \%) \\
\text { Second: } 4(26.7 \%) \\
\text { Third: } 2(13.3 \%)\end{array}$ \\
\hline
\end{tabular}

ASD: autism spectrum disorder; ICP: infantile cerebral palsy.

\section{Statistical analysis}

The software used for data processing in this study was SPSS version 22.0 (IBM SPSS Statistics for Windows Version 22.0, Armonk, NY, USA; IBM Corp.) Normality distribution was assessed using the Kolmogorov-Smirnov test. A descriptive analysis was performed to obtain medians and ranges the distribution of the variables.

\section{Results}

A total of 15 patients were included, with an average age of 5 years (range 1-17), of which nine patients $(60 \%)$ corresponded to patients with ASD and the rest of the patients with ICP. In 9 of the patients $(60 \%)$, both the BMA and LP procedures were being conducted for the $1^{\text {st }}$ time, while in 4 patients $(26.7 \%)$, the procedure was performed for the $2^{\text {nd }}$ time, and two patients $(13.3 \%)$ were undergoing their third procedure (Table 1).

We found a variation between baseline scores and those posterior to the procedure in evaluations conducted by caregivers and those performed by medical personnel. In the first evaluation, all 15 patients (100\%) presented scores of $<7$ in the lists performed by the medical personnel. In contrast, caregivers identified values of $<7$ in only 12 patients $(80 \%)$ before performing BMA and LP.

Regarding the scores obtained in the second survey (30 min after BMA and LP), the caregivers reported $<7$ points in 10 patients $(66.7 \%)$, contrary to medical personnel, who identified that there was no pain in 13 patients $(86.7 \%)$. Different values were found in the
Table 2. Number of patients who had $<7$ pain response points on the "Non-Communicating Children's Pain Checklist-Revised" checklist

\begin{tabular}{|l|c|c|}
\hline Survey taken & $\begin{array}{c}\text { Caretaker } \\
\text { n (\%) }\end{array}$ & $\begin{array}{c}\text { Medical } \\
\text { personnel n (\%) }\end{array}$ \\
\hline Before the procedure & $12(80)$ & $15(100)$ \\
\hline 30 min after the procedure & $10(66.7)$ & $13(86.7)$ \\
\hline $24 \mathrm{~h}$ after the procedure & $8(53.3)$ & $10(66.7)$ \\
\hline
\end{tabular}

Results obtained in the pain surveys carried out by the caregiver and the medical team in their 3 times of application.

Table 3. Items with higher scores in lists applied by caregivers

\begin{tabular}{|c|c|c|c|c|}
\hline \multirow[b]{2}{*}{$\begin{array}{l}\text { Survey at } \\
30 \text { min } \\
\text { after } \\
\text { procedure }\end{array}$} & \multicolumn{2}{|c|}{$\begin{array}{c}\text { ICP } n=6 \text { Average } \\
(m i n-\max )\end{array}$} & \multicolumn{2}{|c|}{$\begin{array}{c}\text { ASD } n=9 \text { Average } \\
(\min -\max )\end{array}$} \\
\hline & $\begin{array}{l}\text { Verbal } \\
\text { expression } \\
\text { Facial } \\
\text { expression } \\
\text { Activity }\end{array}$ & $\begin{array}{l}2(0-6) \\
1(0-12) \\
1.5(0-6)\end{array}$ & $\begin{array}{l}\text { Verbal } \\
\text { expression } \\
\text { Social attitude } \\
\text { Facial } \\
\text { expression } \\
\text { Activity }\end{array}$ & $\begin{array}{l}0(0-4) \\
0(0-4) \\
0(0-3) \\
1(0-3)\end{array}$ \\
\hline $\begin{array}{l}\text { Survey at } \\
24 \text { h after } \\
\text { procedure }\end{array}$ & $\begin{array}{l}\text { Verbal } \\
\text { expression } \\
\text { Social } \\
\text { attitude } \\
\text { Facial } \\
\text { expression }\end{array}$ & $\begin{array}{l}3(0-8) \\
3(0-5) \\
2(0-8)\end{array}$ & $\begin{array}{l}\text { Social attitude } \\
\text { Activity }\end{array}$ & $\begin{array}{l}0(0-6) \\
1(0-2)\end{array}$ \\
\hline
\end{tabular}

ASD: autism spectrum disorder; ICP: infantile cerebral palsy.

applications performed by the caregivers at $24 \mathrm{~h}$ as well: $<7$ points in 8 patients $(53.3 \%)$, as opposed to in 10 patients $(66.7 \%)$ in those conducted by the medical team (Table 2).

In the surveys conducted in patients with a diagnosis of ICP as well as ASD, the items evaluated by the caregivers with the greatest scores after the procedures were those corresponding to facial expression, verbal expression, social attitude, and activity (Table 3 ).

\section{Discussion}

ICP is a motor neurodevelopmental syndrome considered as the main cause of motor disability among children ${ }^{21}$. On the other hand, ASD is a syndrome characterized by its effects on social communication and repetitive and restricted sensory-motor conducts ${ }^{22}$. The management of both illnesses ought to be multidisciplinary and focused on improving the patient's quality of life and independence ${ }^{23,24}$. 
Studies show an improvement among these children when they undergo cellular therapy ${ }^{12-14}$. While it cannot be considered a curative treatment, it can be considered a possibility to improve the poor quality of life of these patients may be living. When using BM as a source for stem cells to later apply them intrathecally ${ }^{10,15}$, it is possible to observe different adverse effects, which may or may not be related to the procedures performed to obtain and apply the cells to the patient. These adverse effects often include pain in the BMA sites (posterosuperior iliac spine) and pain in the LP ${ }^{10,12}$.

Despite the challenges that the evaluation of pain in children with ICP or ASD presents due to communication problems, timely pain identification is essential to provide early treatment. In our patients, the pain was easily controlled with the use of non-steroidal autoinflammatory medication and paracetamol.

Authors who have performed this type of procedure in patients with ASD and ICP mentioned pain as an adverse event related to BMA and LP8,10. However, they did not mention in their methodology how they evaluated the perception of pain in these children.

To the best of our knowledge, pain evaluation in patients with neurological conditions who undergo BMA and LP has not been assessed objectively with validated scales for non-verbal patients because these are not routine procedures in patients with these diagnoses.

In this study, pain after an outpatient procedure was evaluated, but it is relevant to consider the comorbidities inherent to these pain-causing conditions. Above all, in patients with ICP who have problems with increased muscle tone, causing musculoskeletal pain ${ }^{25}$, which could explain why caregivers gave scores of $\geq 7$ in 3 of the patients diagnosed with ICP in our population, even before the process.

Our preliminary results highlight the importance of certain specific behaviors that can be observed during a pain episode in non-verbal patients. It is worth mentioning that there is a difference in the values reported between caregivers and medical personnel because it has been found that knowing the patient for at least 6 months $^{26,27}$ makes it easier to identify the items in the NCCPC-r. In contrast, medical personnel is only in contact with patients for 5 days. However, the perception and, therefore, the score of the caregivers may be affected by their affective bond and the subjectivity that this bond with the patient entails.

The items with the highest efficacy in identifying pain by caregivers were facial expression, social attitude, activity, and verbal expression ${ }^{26}$, which were consistent with our results. Our preliminary results showed that the pain was well-tolerated and easy to control. Because of the difficulty of identifying pain in these patients, knowing the relevance of these items as a response to pain in a child unable to verbally convey this sensation, especially for people outside their care, is a truly useful tool.

\section{Conclusions}

It is possible that the standard procedures carried out for the diagnosis and treatment of diseases in the central nervous system in hematological patients, such as BMA and LP, may be thought to be extremely aggressive and not well tolerated despite analgesics for the disease, such as the non-steroidal ones. These procedures are now also performed in patients with non-hematological diagnoses, such as children with ICP and ASD, who are unable to express pain verbally. However, with the preliminary data obtained through the evaluations carried out by their caregivers, it can be shown that this type of procedure is safe and well-tolerated by this group of patients and can be considered as a therapeutic alternative to improve their current condition without compromising their quality of life ${ }^{15,28,29}$.

\section{Acknowledgments}

The authors wish to express their sincere thanks to all the patients and family members for their help and their participation in this study.

\section{Funding}

This study was financed by the resources belonging to the Hematology Service of the "Dr. José Eleuterio González" University Hospital of the Universidad Autónoma de Nuevo León.

\section{Conflicts of interest}

The authors declare having no conflicts of interest that have to be mentioned.

\section{Ethical disclosures}

Protection of human and animal subjects. The authors declare that the procedures followed were in accordance with the regulations of the relevant clinical research ethics committee and with those of the Code of Ethics of the World Medical Association (Declaration of Helsinki). 
Confidentiality of data. The authors declare that they have followed the protocols of their work center on the publication of patient data.

Right to privacy and informed consent. The authors have obtained the written informed consent of the patients or subjects mentioned in the article. The corresponding author is in possession of this document.

\section{References}

1. Beléndez $C$, Cela E, Galarón P. Punción-aspiración de médula ósea. An Pediatr Contin. 2007:5:52-4

2. Liu Q, Chai XM, Zhang JJ, Wang YL, Wang Y, Gao LL, et al. A fixed nitrous oxide and oxygen mixture for analgesia in children with leukemia with lumbar puncture-induced pain: a randomized, double-blind controlled trial. J Pain Symptom Manage. 2019:57:1043-50.

3. Ghasemi A, Gharavi Fard M, Sabzevari A. General anesthesia for lumbar puncture and bone marrow aspiration/biopsy in children with cancer. Iran J Pediatr Hematol Oncol. 2013;3:54-8.

4. Ogliari KS, Marinowic D, Brum DE, Loth F. Stem cells in dermatology. An Bras Dermatol. 2014;89:286-91

5. Eaton S, Zani A, Pierro A, De Coppi P. Stem cells as a potential therapy for necrotizing enterocolitis. Expert Opin Biol Ther. 2013;13:1683-9.

6. Syková E, Homola A, Mazanec R, Lachmann H, Konrádová ŠL, Kobylka $P$, et al. Autologous bone marrow transplantation in patients with subacute and chronic spinal cord injury. Cell Transplant. 2006;15:675-87.

7. Mehta T, Feroz A, Thakkar U, Vanikar A, Shah V, Trivedi H. Subarachnoid placement of stem cells in neurological disorders. Transplant Proc. 2008;40:1145-7.

8. Boruczkowski D, Pujal JM, Zdoli囚ska-Malinowska I. Autologous cord blood in children with cerebral palsy: a review. Int J Mol Sci. 2019;20:2433.

9. Eggenberger S, Boucard C, Schoeberlein A, Guzman R, Limacher A Surbek D, et al. Stem cell treatment and cerebral palsy: systemic review and meta-analysis. World J Stem Cells. 2019;11:891-903.

10. Sharma A, Gokulchandran N, Sane H, Nagrajan A, Paranjape A, Kulkarni $\mathrm{P}$, et al. Autologous bone marrow mononuclear cell therapy for autism: an open label proof of concept study. Stem Cells Int. 2013;2013:623875

11. Ichim TE, Solano F, Glenn E, Morales F, Smith L, Zabrecky G, et al. Stem cell therapy for autism. J Transl Med. 2007;5:1-9.

12. Chen G, Wang $Y, X u Z$, Fang $F, X u R$, Wang $Y$, et al. Neural stem ceII-like cells derived from autologous bone mesenchymal stem cells for the treatment of patients with cerebral palsy. J Transl Med. 2013;11:1-11.

13. Wang $X$, Cheng $H$, Hua $R$, Yang J, Dai G, Zhang Z, et al. Effects of bone marrow mesenchymal stromal cells on gross motor function measure scores of children with cerebral palsy: a preliminary clinical study. Cytotherapy. 2013;15:1549-62.
14. Larijani B, Foroughi Heravani N, Alavi-Moghadam S, Goodarzi P, Rezaei-Tavirani M, Payab M, et al. Cell Therapy Targets for Autism Spectrum Disorders: hopes, Challenges and Future Directions. New York, NY: Springer; 2020. p. 1-18.

15. Mancías-Guerra C, Marroquín-Escamilla AR, Valdés-Burnes SL, Barrera-Morales DC, Jaime-Pérez JC, Rodríguez-Romo LN, et al. Safety and tolerability of intrathecal delivery of autologous bone marrow nucleated cells in children with cerebral palsy: an open-label phase I trial. Cytotherapy. 2014;16:810-20.

16. Blackman JA, Svensson $\mathrm{Cl}$, Marchand S. Pathophysiology of chronic pain in cerebral palsy: implications for pharmacological treatment and research. Dev Med Child Neurol. 2018;60:861-5.

17. Summers J, Shahrami A, Cali S, D'Mello C, Kako M, Palikucin-Reljin A, et al. Self-injury in autism spectrum disorder and intellectual disability: exploring the role of reactivity to pain and sensory input. Brain Sci. 2017:7:1-16.

18. Manworren RC, Stinson J. Pediatric pain measurement, assessment and evaluation. Semin Pediatr Neurol. 2016;23:189-200.

19. Breau LM, Mcgrath PJ, Camfield CS, Finley GA. Psychometric properties of the non-communicating children's pain checklist-revised. Pain. 2002;99:349-57

20. Gómez Iruretagoyena Jl, Agüeria Álvarez S. Cuestionario NCCPC-r. Cantabria: Gimbernat-Cantabria; 2019.

21. López-Santacruz HD, Hernández-Molinar Y, Martínez-Sandoval BE, Ángel M, Torre-Delgadillo $G$. Estrategias terapéuticas de calidad en odontopediatría : parálisis cerebral. Acta Pediátr México. 2019;40:32-43.

22. Lord C, Elsabbagh M, Baird G, Veenstra-Vanderweele J. Autism spectrum disorder. Lancet. 2018;392:508-20.

23. Secretaría de Salud. Guía de Práctica Clínica Abordaje y Manejo de Niño con Parálisis Cerebral Infantil con Comorbilidades Neurológicas y Músculo Esqueléticas. México: Secretaría de Salud; 2010.

24. Gulati S, Sondhi V. Cerebral palsy: an overview. Indian J Pediatr. 2018;85:1006-16.

25. Ramstad K, Jahnsen R, Skjeldal OH, Diseth TH. Characteristics of recurrent musculoskeletal pain in children with cerebral palsy aged 8 to 18 years. Dev Med Child Neurol. 2011:53:1013-8.

26. Breau LM, McGrath PJ, Camfield C, Rosmus C, Allen Finley G. Preliminary validation of an observational pain checklist for persons with cognitive impairments and inability to communicate verbally. Dev Med Child Neurol. 2000;42:609-16.

27. Breau LM, Camfield C, McGrath PJ, Rosmus C, Finley GA. Measuring pain accurately in children with cognitive impairments: refinement of a caregiver scale. J Pediatr. 2001;138:721-7.

28. Mancias-Guerra MC, Velasco-Ruiz IY, Carreño-Salcedo SA, Huerta-Rangel R. TCP0005-TL: percepción de los padres acerca de los efectos secundarios y resultados obtenidos en el tratamiento con células nucleadas totales en pacientes con parálisis cerebral y autismo. Rev Hematol Mex. 2021;22:S286.

29. Velasco-Ruiz IY, Valencia-Alcocer Al, Sánchez-García SA, López-Quezada JC, Mancias-Guerra MC. TCP0029-TL: efectos secundarios asociados a la aplicación intratecal de células nucleadas totales de médula ósea autóloga en pacientes con parálisis cerebral y autismo, experiencia de 10 años. Rev Hematol Mex. 2021;22:S286. 